\title{
PENGGUNAAN TANGKAI PEGANGAN ROLLER CAT YANG DIMODIFIKASI MENINGKATKAN KINERJA PENGECAT PLAFON RUKAN DI DENPASAR
}

\author{
I Gusti Agung Haryawan ${ }^{1}$; I Dewa Putu Sutjana ${ }^{2}$; I Made Sutajaya ${ }^{3}$ \\ agung.haryawan@yahoo.co.id \\ Mahasiswa ${ }^{1}$; Pembimbing I²; Pembimbing II $^{3}$ \\ Program Studi Ergonomi-Fisiologi Kerja, Program Pascasarjana Universitas Udayana
}

\begin{abstract}
Buildings development is very glowing recently. This also has effect on manpower who works at this sector. Manpower is demanded to have skill according to his field. Worker at finishing field or especially for ceiling painter needs skill and technique that he should master. While working the worker always assists by tools and paint materials. Tools that are used by the ceiling painter have not been refered to antropometry aspect, so it can cause inconvenient in performing the job. Working with toold that are not accorded to ergonomic principle and working posture that is not physiological can cause fatigue, muscle disturbance, musculoskeletal and increasing working load. That is why it needs to modify painting roller holder stick. In that case the worker can work in comfort, safe, healthy, efficient and productive so it can increase productivity.
\end{abstract}

This research was perfomed at office house at Denpasar City. Type of this research is experimental research by using treatment by subject design by involving 16 samples. Interval between before treatment and after treatment is given washing out for two days. Data measured are the working load measured by the increasing of subjective complaint recorded by Nordic Body Map questionnaire, pulses, fatigue and working productivity. Data of subjective complaint was analyzed by non-parametric statistic test using the Wilcoxon test with significance rate of $\alpha=0.05$, data of pulses as indicator of working load, working productivity was priorly data normality tested by Shapiro-Wilk Test with significance rate of $\alpha$ $=0.05$. Data that normal distributed is continued with parametric statistic test using the $\mathrm{t}-$ paired test at significance rate of $\alpha=0.05$.

Research result shows that there is significant different $(p<0.05)$ to working load variable, musculoskeletal complaint, fatigue and productivity. At before treatment the average of pulses of ceiling painter is $118.95 \pm 2.30 \mathrm{dpm}$, average of musculoskeletal complaint is $78.50 \pm 5.84$, average of fatigue is $74.22 \pm 388$ and average of productivity is $0,070 \pm 0,017$. Whereas, at after treatment the average of pulses of ceiling painter is $111.89 \pm 6.58 \mathrm{dpm}$, average of musculoskeletal complaint is $61.61 \pm 1.71$, average of fatigue is $64.50 \pm 2.88$ and average of productivity is $0,086 \pm 0,070$. Modification of painting roller holder stick turned out to decrease working load for $10,77 \%$, musculoskeletal complaint for $21,51 \%$, fatigue for $13,09 \%$, and productivity is increasing for $22,85 \%$.

From discussion above it can be concluded that the modification of painting roller holder stick can decrease working load, musculoskeletal complaint, fatigue, and increase productivity. In that case, it can be expected that the ceiling painter workers use this painting roller holder stick in order to minimize any complaint raises due to working process.

Key Words: Painting Holler Holder Stick, Modification, Performance, Ceiling Painter 


\section{ABSTRAK}

Pembangunan gedung-gedung sangat marak belakangan ini. Ini juga berimbas pada tenaga kerja yang bekerja di sektor ini. Tenaga kerja dituntut memiliki keterampilan sesuai dengan bidangnya. Pekerja di bidang finishing atau lebih mengkhusus pada pengecat plafon sangat memerlukan keterampilan dan teknik yang harus dikuasai. Pada saat bekerja pekerja selalu dibantu dengan alat dan bahan cat. Alat yang digunakan oleh pengecat plafon belum mengacu pada aspek antropometri, sehingga dapat menimbulkan ketidaknyamanan dalam melakukan pekerjaan. Bekerja dengan peralatan yang tidak sesuai dengan kaedah ergonomi serta sikap kerja yang tidak fisiologis dapat menyebabkan kelelahan, gangguan otot, muskuloskeletal dan beban kerja meningkat. Untuk itu perlu dilakukan modifikasi tangkai pegangan roller cat. Sehingga pekerja bekerja dengan nyaman, aman, sehat, efisien dan produktif sehingga produktivitas dapat ditingkatkan.

Penelitian ini dilakukan di rukan Kota Denpasar. Jenis penelitian ini adalah penelitian eksperimental dengan menggunakan rancangan sama subjek (treatment by subject design) dengan melibatkan 16 orang sampel. Selang antara sebelum perlakuan dan sesudah perlakuan diberikan washing out selama dua hari. Data yang diukur adalah beban kerja diukur dari peningkatan keluhan subjektif dicatat dengan kuesioner Nordic Body Map, denyut nadi, kelelahan dan produktivitas kerja. Data keluhan subjektif dianalisis dengan uji statistic non parametric menggunakan uji Wilcoxon dengan tingkat kemaknaan $\alpha=0,05$, data denyut nadi sebagai indikator beban kerja, produktivitas kerja terlebih dahulu diuji normalitas data dengan uji Shapiro-Wilk Test dengan tingkat kemaknaan $\alpha=0,05$. Data berdistribusi normal dilanjutkan dengan uji statistic parametric menggunakan uji t-paired test pada tingkat kemaknaan $\alpha=0,05$.

Hasil penelitian menunjukkan adanya perbedaan bermakna $(\mathrm{p}<0,05)$ pada variabel beban kerja, keluhan muskuloskeletal, kelelahan dan produktivitas. Pada sebelum perlakuan rerata denyut nadi kerja pengecat plafon adalah 118,95 $\pm 2,30 \mathrm{dpm}$, rerata dan keluhan muskuloskeletal adalah 78,50 $\pm 5,84$, rerata kelelahan adalah 74,22 \pm 388 dan rerata produktivitas adalah $0,070 \pm 0,017$. Sedangkan pada sesudah perlakuan rerata denyut nadi kerja pengecat plafon adalah $111,89 \pm 6,58 \mathrm{dpm}$, rerata keluhan muskuloskeletal adalah 61,61 $\pm 1,71$, rerata kelelahan adalah $64,50 \pm 2,88$ dan rerata produktivitas adalah $0,086 \pm 0,070$. Modifikasi tangkai pegangan roller cat ternyata menurunkan beban kerja sebesar $10,77 \%$, keluhan muskuloskeletal sebesar $21,51 \%$, kelelahan $13,09 \%$, dan produktivitas meningkat sebesar 22,85\%.

Dari pembahasan tersebut dapat disimpulkan bahwa modifikasi tangkai pegangan roller cat dapat menurunkan beban kerja, keluhan muskuloskeletal, kelelahan, dan meningkatkan produktivitas. Sehingga dapat diharapkan kepada para pekerja pengecat plafon untuk menggunakan tangkai pegangan roller cat ini agar dapat meminimalkan setiap keluhan yang ditimbulkan akibat proses kerja.

Kata Kunci : Tangkai Pegangan Roller Cat, Modifikasi, Kinerja, Pengecat Plafon 
ISSN Print : 1411 - $951 \mathrm{X}$, ISSN Online : 20503-1716

Jurnal Ergonomi Indonesia

(The Indonesian Journal of Ergonomic)

\section{Latar Belakang}

Pekerjaan disektor konstruksi pada pembangunan gedung-gedung, perumahan dan lainnya sangatlah marak pada saat ini. Dimana pada proses pembangunan tersebut selalu melibatkan pihak perencana baik seorang arsitek maupun seorang designer interior dan para pekerja. Saat pengerjaan bangunan diperlukan pengawasan yang baik terhadap kwalitas pekerjaan tersebut. Tenaga kerja sangat berperan penting dalam mewujudkan bangunan yang baik, aman dan nyaman.

Tenaga kerja dituntut mempunyai keterampilan yang standar sesuai dengan bidangnya masing-masing. Bekerja mengecat plafon haruslah mempunyai teknik dan keterampilan khusus, karena menyangkut hasil dari pekerjaan akhir dalam sebuah ruangan atau bangunan. Hasil pengecatan harus sesuai dengan desain yang ada, rapi dan baik.

Plafon dalam beberapa istilah disebut dengan awang-awang atau langit-
Vol.2, No.2 : 1 Juli-Desember 2016

langit. Kata plafon yang sekarang digunakan berasal dari bahasa Belanda, plafond yang merujuk pada makna garis batas, biasanya horizontal antara dinding dan atap (Imelda 2012). Dalam dunia arsitektur dan desain interior, plafon berarti batas permukaan atas interior ruang yang merupakan media untuk menutup atap.

Material plafon yang banyak digunakan dan paling mudah perawatannya adalah dari bahan gypsum dan kalsiboard. Teknik finishingnya berupa dicat, warna disesuaikan dengan keinginan pemakainya. Bahan lainnya juga ada seperti multiplek, papan kayu, anyaman rotan atau gedeg, yang mempunyai finishing yang berbedabeda.

Dalam melakukan pekerjaan mengecat plafon, para pekerja mengambil sikap berdiri, kepala menengadah dan tangan diangkat keatas sambil memegang tangkai pegangan roller cat dari kayu dengan lebar penampang $2 \times 3 \mathrm{~cm}$. Para pekerja tidak menyiapkan peralatan yang 
ISSN Print : 1411 - $951 \mathrm{X}$, ISSN Online : 20503-1716

Jurnal Ergonomi Indonesia

(The Indonesian Journal of Ergonomic)

khusus dalam melaksanakan pekerjaannya, mereka mencari alat atau tangkai disekitar tempat kerja, tentunya tidak sesuai dengan ukuran yang diperlukan.

Hasil pengamatan di lapangan dan studi pendahuluan menunjukkan pengecat plafon bekerja dengan sikap kerja yang tidak fisiologis, hal ini mengakibatkan pengecat plafon bekerja dengan postur tubuh yang sedikit menjinjit, kepala menengadah dan pada telapak tangan merasa sakit karena menggenggam alat yang tidak sesuai dengan antropometri tubuh, sehingga menimbulkan keluhankeluhan pada tubuh diantaranya disekitar leher(60\%), pada bahu kiri dan kanan (73\%), pada lengan atas kiri dan kanan (75\%), pada betis kiri dan kanan $(60 \%)$ dan pada tangan $(75 \%)$.

Peralatan kerja yang belum sesuai dengan antropometri pemakainya perlu dilakukan perbaikan, setiap usaha perbaikan peralatan kerja hendaknya bersifat sederhana serta murah biayanya,
Vol.2, No.2 : 1 Juli-Desember 2016

bisa dan mudah dilakukan, dapat memberikan keuntungan secara ekonomi (Manuaba, 1992a).

Berdasarkan permasalahan tersebut dipandang perlu untuk mendesain alat kerja yang sesuai dengan kaidah-kaidah ergonomi sehingga faktor resiko akibat pekerjaan dapat berkurang. Oleh karena itu penggunaan tangkai pegangan roller cat yang dimodifikasi dengan panjang tangkai $188 \mathrm{~cm}$, diameter tangkai $3,5 \mathrm{~cm}$ dan dengan berat 500 gram.

Dengan penggunaan tangkai pegangan roller cat yang dimodifikasi dapat menurunkan beban kerja sebesar 10,77\%, menurunkan keluhan muskuloskeletal sebesar $\quad 21,51 \%$, menurunkan kelelahan sebesar 13,09\% dan meningkatkan produktivitas sebesar $22,85 \%$.

\section{Metode Penelitian}

Penelitian ini dilakukan di rumah kantor (rukan) Duta Wijaya, Renon, Denpasar. Pengambilan data dilakukan dari 
ISSN Print : 1411 - $951 \mathrm{X}$, ISSN Online : 20503-1716

Jurnal Ergonomi Indonesia

(The Indonesian Journal of Ergonomic)

tanggal 5 Januari 2014 sampai tanggal 5

Maret 2014. Waktu pengambilan data berlangsung antara pukul $08.00-17.00$

Wita.

Populasi target pada penelitian ini adalah semua pekerja laki-laki pengecat plafon yang memiliki keterampilan pada bidangnya. Populasi terjangkau adalah pekerja laki-laki pengecat plafon daerah renon dan sekitarnya.

Sampel yang ditetapkan layak dilibatkan dalam penelitian ini didasarkan pada kriteria inklusi adalah pekerja lakilaki pengecat plafon, umur berkisar antara 18-45 tahun, pengalaman kerja minimal 1 tahun, bersedia menjadi subjek penelitian, dalam kondisi sehat, tidak dalam pengaruh obat-obatan yang dapat mempengaruhi hasil penelitian, dan mampu mengikuti penelitian hingga akhir.

Hasil perhitungan jumlah sampel dengan rumus Colton didapatkan jumlah sampel terbesar 14 orang ditambah $15 \%$ untuk menghindari dropout, sehingga
Vol.2, No.2 : 1 Juli-Desember 2016

sampel menjadi 15 orang. Teknik penentuan sampel yang digunakan dalam penelitian ini adalah acak sederhana (simple random sampling) menggunakan table bilangan random. Populasi terjangkau sebanyak 25 orang, yang memenuhi kriteria inklusi dan eksklusi sebanyak 20 orang. Jumlah sampel yang diperlukan dalam penelitian ini adalah 16 orang.

Penelitian eksperimental ini menggunakan rancangan sama subjek (treatment by subject design) dimana pada perlakuan satu menggunakan tangkai pegangan dari kayu reng penampang $2 \times 3$ $\mathrm{cm}$ dengan panjang $200 \mathrm{~cm}$ dan perlakuan dua menggunakan tangkai pegangan dari bamboo dengan panjang $188 \mathrm{~cm}$ dan berdiameter $3,5 \mathrm{~cm}$.

Digunakan kuesioner Nordic body map untuk menilai keluhan musculoskeletal dan kuesioner 30 item kelelahan dengan empat skala Likert untuk menilai kelelahan subjek penelitian. Hasil penelitian seluruh data variable yang 
ISSN Print : 1411 - $951 \mathrm{X}$, ISSN Online : 20503-1716

Jurnal Ergonomi Indonesia

(The Indonesian Journal of Ergonomic)

Vol.2, No.2 : 1 Juli-Desember 2016

diteliti berdistribusi normal, maka

sebelum perlakuan dan sesudah perlakuan digunakan analisis statistik parametrik $t$ paired.

\section{Hasil dan Pembahasan}

Hasil wawancara dan pengisian kesioner semua subjek sebanyak 16 orang bersuku Jawa. Riwayat pendidikan 4 orang tamat SD, 7 orang tamat SMP dan 5 orang tamat SMA. Rerata umur subjek yang terlibat dalam penelitian ini adalah $25,87 \pm 5,16$ tahun dengan rentangan antara 18-45 tahun. Dapat dikatakan bahwa rentangan umur subjek tersebut masih produktif. Rerata berat badan subjek $54,75 \pm 5,35 \mathrm{~kg}$, sedangkan tinggi badan subjek reratanya $162,99 \pm 2,94 \mathrm{~cm}$, dan rerata pengalaman kerja adalah $7,50 \pm 2,90$ tahun.

Rerata kelembaban relatif sebelum perlakuan adalah $79,30 \pm 2,27 \%$ dan kelembabab relatif sesudah perlakuan rerata $79,18 \pm 2,37 \%$. Dari analisis uji normalitas dengan uji Shapiro-Wilk diperoleh bahwa kelembaban relatif tidak ada perbedaan secara bermakna $(p>0,05)$ data berdistribusi normal. Hasil analisis uji t-paired test diperoleh kelembaban relatif sebelum dan sesudah perlakuan tidak ada perbedaan secara bermakna $(p>0,05)$. Dengan demikian suhu lingkungan ruang pengecatan plafon tidak memberikan pengaruh terhadap jalannya penelitian.

$$
\text { Hasil pengukuran intensitas }
$$
kebisingan sebelum perlakuan dengan rerata $45,10 \pm 2,01 \mathrm{dBA}$ dan sesudah perlakuan dengan rerata $45,00 \pm 2,05 \mathrm{dBA}$ yang sebagian besar berasal dari percakapan antar subjek penelitian selama melakukan pengecatan plafon. Kondisi ini masih termasuk di bawah nilai ambang batas kebisingan yaitu 80dBA (Mangunwijaya,2000) sehingga tidak sampai mengganggu aktivitas pengecatan plafon rukan Denpasar.

Dari hasil pemantauan dan pengukuran selama penelitian berlangsung 
ISSN Print : 1411 - $951 \mathrm{X}$, ISSN Online : 20503-1716

Jurnal Ergonomi Indonesia

(The Indonesian Journal of Ergonomic)

didapatkan rerata intensitas penerangan sebelum dan sesudah perbaikan $356,11 \pm$ 8,25 lux. Intensitas penerangan ini dianalisis dengan uji t-paired ternyata tidak berbeda bermakna $(p>0,05)$.

Hasil analisis rerata denyut nadi istirahat pada masing-masing perlakuan adalah tidak berbeda secara signifikan $(\mathrm{p}<0,05)$, artinya bahwa kondisi denyut nadi awal subjek bisa dianggap sama atau memberikan pengaruh yang sama terhadap masing-masing perlakuan. Rerata denyut nadi kerja subjek pada sebelum perlakuan adalah $118,95 \pm 2,30$ dpm termasuk kategori beban kerja sedang. Rerata denyut nadi
Vol.2, No.2 : 1 Juli-Desember 2016

kerja subjek penelitian pada sesudah perlakuan adalah $111,90+6,58 \mathrm{dpm}$ yang termasuk ke dalam kategori kerja sedang. Nadi kerja pada stasiun kerja sebelum perlakuan reratanya $54,45 \pm 3,37 \mathrm{dpm}$ dan pada stasiun kerja sesudah perlakuan $48,15 \pm 3,56$ dpm, dapat di lihat pada Tabel 1. Menurunnya beban kerja disebabkan dengan penggunaan tangkai pegangan roller cat yang sudah mengacu pada antropometri pekerja memberikan kenyamanan pada saat bekerja, sehingga beban kerja dirasakan lebih ringan dan kondisi tubuh masih bisa santai.

Tabel 1 Uji Perbedaan Skor Denyut Nadi Pekerja Pengecat Plafon ( $\mathrm{n}=16)$

\begin{tabular}{|c|c|c|c|c|c|c|c|}
\hline \multirow{2}{*}{ Variabel } & \multicolumn{3}{|c|}{ Periode I } & \multicolumn{2}{|c|}{ Periode II } & \multirow{2}{*}{$\begin{array}{l}\text { Nilai } \\
\mathrm{t}\end{array}$} & \multirow{2}{*}{$\begin{array}{l}\text { Nilai } \\
p\end{array}$} \\
\hline & $\mathrm{n}$ & Rerata & SB & Rerata & SB & & \\
\hline $\begin{array}{l}\text { Denyut nadi } \\
\text { istirahat }\end{array}$ & 16 & 64,50 & 2,76 & 63,75 & 2,74 & 0,771 & 0,447 \\
\hline Denyut nadi kerja & 16 & 118,95 & 2,30 & 111,89 & 6,58 & 0,001 & 4,043 \\
\hline Nadi kerja & 16 & 54,45 & 3,37 & 48,15 & 3,56 & 0,001 & 5,107 \\
\hline
\end{tabular}

Berdasarkan hasil penelitian bekerja. Pada uji t-paired sesudah didapatkan bahwa rerata skor kelelahan perlakuan didapatkan skor kelelahan

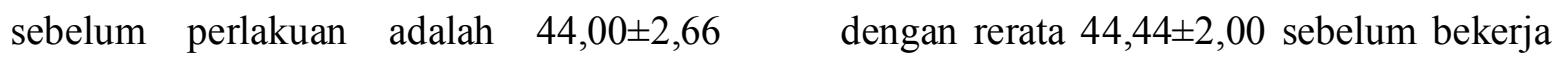


ISSN Print : 1411 - $951 \mathrm{X}$, ISSN Online : 20503-1716

Jurnal Ergonomi Indonesia

(The Indonesian Journal of Ergonomic)

dan $64,50 \pm 2,88$ sesudah bekerja. Data

rerata beda skor kelelahan sebelum

perlakuan adalah $30,62 \pm 4,51$ dan

$20,06 \pm 3,29$ setelah perlakuan. Hasil uji

efek perbedaan skor sebelum dan sesudah

kerja sebelum perlakuan dengan sebelum

kerja dan sesudah kerja sesudah perlakuan

menggunakan uji Wilcoxon menunjukkan

$\mathrm{p}=0,005$ yang artinya berbeda secara

signifikan antara sebelum dan sesudah

perlakuan. Dari uraian ini dapat

disimpulkan bahwa perbaikan alat dan cara kerja yang mengacu pada antropometri tangan pengecat plafon dapat mengurangi kelelahan pengecat plafon sebesar 13,09\%. Penurunan kelelahan disebabkan sikap kerja mengecat plafon yang alamiah dan didukung dengan penggunaan tangkai pegangan roller cat yang sesuai dengan antropometri pekerja, memudahkan dalam melakukan pekerjaan mengecat karena ukuran dan berat alat tidak terlalu membebani pekerja dalam beraktivitas.

Tabel 2 Uji Perbedaan Efek Sebelum dan Sesudah Perlakuan Beda Skor

Kelelahan Pekerja Pengecat Plafon $(\mathrm{n}=16)$

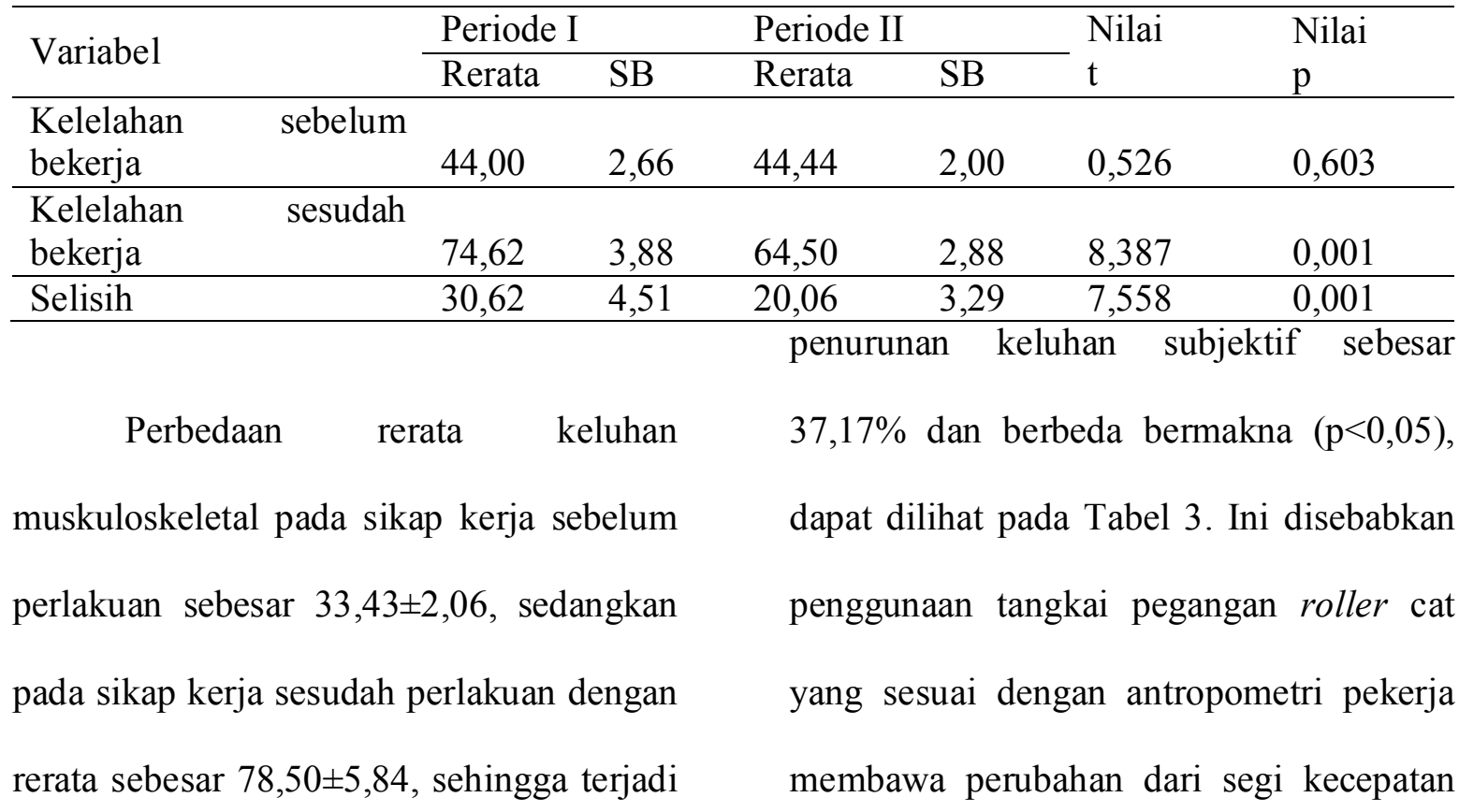


ISSN Print : 1411 - $951 \mathrm{X}$, ISSN Online : 20503-1716

Jurnal Ergonomi Indonesia

(The Indonesian Journal of Ergonomic)

dalam melakukan aktivitasnya. Karena

tubuh atau otot-otot skeletal lainnya.

berat tangkai pegangan roller cat lebih

Dengan demikian perubahan stasiun kerja

ringan sehingga beruntutan dalam bekerja dan penyesuaian antropometri tubuh

mulai dari mengambil cat dibak cat pekerja dapat menurunkan keluhan

dilanjutkan mengecat ke plafon muskuloskeletal.

memberikan cukup waktu yang lebih

nyaman dan santai yang tidak membebani

Tabel 3 Uji Perbedaan Efek Sebelum dan Sesudah Perlakuan Beda Skor Keluhan Muskuloskeletal $(n=16)$

\begin{tabular}{|c|c|c|c|c|c|c|c|}
\hline \multirow{2}{*}{ Variabel } & & \multicolumn{2}{|c|}{ Periode I } & \multicolumn{2}{|c|}{ Periode II } & \multirow{2}{*}{$\begin{array}{l}\text { Nilai } \\
t\end{array}$} & \multirow{2}{*}{$\begin{array}{l}\text { Nilai } \\
\mathrm{p}\end{array}$} \\
\hline & & Rerata & SB & Rerata & SB & & \\
\hline $\begin{array}{l}\text { Kelelahan } \\
\text { bekerja }\end{array}$ & sebelum & 33,43 & 2,06 & 33,31 & 1,66 & 0,189 & 0,852 \\
\hline $\begin{array}{l}\text { Kelelahan } \\
\text { bekerja }\end{array}$ & sesudah & 78,5 & 5,84 & 61,62 & 1,70 & 11,08 & 0,001 \\
\hline Selisih & & 45,06 & 7,28 & 28,31 & 3,04 & 8,480 & 0,001 \\
\hline
\end{tabular}

Dari analisis data diperoleh rerata

produksi kerja pada sebelum perlakuan

$0,070 \pm 0,01$ dan sesudah perlakuan

$0,086 \pm 0,07$ berbeda bermakna, terjadi

peningkatan produksi kerja sebesar $0,016 \%$

dan berbeda bermakna $(p<0,05)$ dapat

dilihat pada Tabel 4. Produktivitas

meningkat disebabkan penggunaan tangkai

pegangan roller cat yang sesuai dengan

antropometri tubuh pekerja, sehingga

mempercepat penyelesaian dalam demikian bidang plafon semakin banyak dapat diselesaikan oleh pekerja, ini berpengaruh kepada hasil atau biaya yang akan diterima oleh pekerja, hasilnya meningkat. 
ISSN Print : 1411 - $951 \mathrm{X}$, ISSN Online : 20503-1716

Jurnal Ergonomi Indonesia

(The Indonesian Journal of Ergonomic)

Vol.2, No.2 : 1 Juli-Desember 2016

Tabel 4 Uji Beda Efek Skor Produktivitas Pekerja Pengecat Plafon Periode I dan Periode II

$(n=16)$

\begin{tabular}{|c|c|c|c|c|c|c|}
\hline \multirow[t]{2}{*}{ Variabel } & \multicolumn{2}{|c|}{ Periode I } & \multicolumn{2}{|c|}{ Periode II } & $\begin{array}{c}\text { Nilai } \\
\mathrm{t}\end{array}$ & $\begin{array}{c}\text { Nilai } \\
p\end{array}$ \\
\hline & Rerata & SB & Rerata & SB & & \\
\hline Produktivitas $\left(\mathrm{m}^{2}\right)$ & 0,070 & 0,01 & 0,086 & 0,07 & 8,815 & 0,001 \\
\hline
\end{tabular}

\section{Simpulan dan Saran}

Dari uraian tersebut diatas dapat disimpulkan bahwa penggunaan tangkai roller cat yang dimodifikasi pada pengecat plafon rukan di denpasar dapat menurunkan beban kerja 10,77\%, menurunkan keluhan muskuloskeletal sebesar 21,51\%, menurunkan kelelahan sebesar 13,09\% dan meningkatkan produktivitas sebesar $22,85 \%$. Oleh karena itu pengecat plafon disarankan menggunakan tangkai pegangan roller cat yang sesuai dengan antropometri dan bekerja secara fisiologis untuk mengurangi beban kerja, keluhan muskuloskeletal, kelelahan,dan meningkatkan produktivitas.

\section{Refference}

Adiputra, N. 1998. Metodelogi Ergonomi. Denpasar: Program Studi Ergonomi
Adiputra, N. 2002. Denyut Nadi dan Kegunaannya Dalam Ergonomi. Jurnal Ergonomi Indonesia. Vol. 3. No. 16: 22-26

Bakta, I M. 2000. Rancangan Penelitian. Disampaikan Pada Seminar Metodologi Penelitian, Fakultas Kedokteran, Universitas Udayana, Denpasar.

Bhattacharjee and Mc Glothlin, J. 1996. Occupational Ergonomics; Theory and Applications, New York, Basel. Hongkong: Marcel Dekker, Inc

Bridger, R.S. 1995. Introduction to Ergonomics Singapore : McGrawHill.

Colton,T.1985. Statistic in Medicine. First Edition. Boston: Little Brown and Company.

Cormick, Mc. E.J. and Sanders, M.S.1993. Workplace Design. Human Factors in Engeneering and Design. $7 \mathrm{Th}$ Editions. Singapore : Mc Grow-Hill International.

Cummings, B. 2003. Interactive Physiology. San Francisco: Pearson Education Inc.

Dempsey, P.G. 2003. A Survey of Lifting and Lowering Task. International Journal of Industry Ergonomics. $P$ 31 (1) 11-16

Dharmayanti, Cokorde Istri, 2011. Perubahan Sikap Kerja Berdasarkan Kaidah Ergonomi Menurunkan Beban Kerja Dan Keluhan Subjektif Serta Meningkatkan Produktivitas 
Kerja Perajin Bola Mimpi Di Desa Budaga (tesis) Denpasar; Program Magister Ergonomi-Fisiologi Kerja, Program Pascasarjana universitas Udayana.

Dul, J. \& Weerdmeester, 1993. Ergonomics for Beginners a Quick Refernece Guide London: Taylor \& Francis.

Gani, A. 1992. Ekonomi Kesehatan Kerja, Prosiding Seminar, Jakarta, Produktivitas Tenaga Kerja Departemen Kesehatan Dan Departemen tenaga Kerja.

Grandjean, E. 1993. Fitting the Task To the Man. A Textbook of Occupational Ergonomics 5. Edition. London: Taylor \& Francis.

Grandjean, E. Kroemer 2000. Fitting the Task To The Man. A Textbook of Occupational Of Ergonomics. 4 Th Ed. London : Taylor \& Francis.

Hadi, S. 1995. Metodologi Reasearch Jilid $I V$. Yogyakarta: Penerbit Andi Offset

Hardianto Iridiastadi dan Yassierli 2014. Ergonomi Suatu Pengantar. PT. Remaja Rosdakarya, Bandung.

Helander, M.G. and Ahang L. 1995. Fields Studies of Comfort and discomfort in Sitting, Ergonomics J. p. 895-915

Hutagalung, R. 2008. Perbaikan Kualitas Kerja Dengan Menerapkan Pendekatan Ergonomi Meningkatkan Kinerja Buruh Angkat Angkut Tradisional Di Pasar Badung Denpasar. (Disertasi) Denpasar: Program Pascasarjana Universitas Udayana.

Iing. 2015. Ujian Osce Reguler Berorientasi Ergonomi Meningkatkan Kinerja Penguji Di Fakultas Kedokteran Universitas Islam Al-Azhar Mataram. (tesis). Denpasar: Program Pascasarjana Universitas Udayana.
ILO, 1998. Encyclopedia of Accupational Health and Safety. In, Genewa Stellman Editor.

Imelda, A. 2012. Plafon Kreatif, Seri Rumah Ide, Edisi 5/III, Gramedia.

Kilbon, A. 1992. Measurement and Assessment of Dynamic Work. Dalam: Evaluation of Human Work. A Practical Ergonomic Methodology, ed. By Wilson, JR dan Corlett, EN, Taylor and Francis, London:pp. 520-542.pp.641-661.

Kumalasari D. 2006. Analisis Keergonomian Postur Tubuh Penyapu Jalan saat Bekerja dan Usulan Perbaikan Bentuk Fisik Tangkai Sapu Kerja Menggunakan Simulasi Manikin In Catia V5R16 (Skripsi). Jakarta: Universitas Gunadarma.

Kodoatie, J.R. 2000. Analisis Ekonmi Teknik. Jogjakarta : Penerbit Andi

Lilik, S. 2002. Penurunan Landasan Molen Sesuai Ukuran Tubuh Pekerja Dan Pemberian Peneduh Meningkatkan Produktivitas Pengadukan Spesi Beton Secara Tradisional. (Tesis) Program Pasca Sarjana Universitas Udayana, Denpasar.

Mamansari D.U. dan Soalokhe.V.M. 1994. A Need of Ergonomics Consideration for the Design and Development of Agriculture Macheinery in Thailand, Bangkok. Proc. Of the Conference of SEAES, November, P. 21-23.

Mangunwijaya, YB. 2000. Pengantar Fisika Bangunan: Jakarta, Djembatan.

Manuaba, A. 1983. Peningkatan Kondisi di Sektor Industri Kecil. Makalah disampaikan dalam Lokakarya Nasional Peningkatan Kondisi dan Lingkungan Kerja diselenggarakan oleh Depnaker - UNDP - ILO di Jakarta 13-14 Desember. 
Manuaba, A. 1992. Pengaruh Ergonomi Terhadap Produktivitas Tenaga Kerja. Disampaikan Pada Seminar Produktivitas Tenaga Kerja Di Jakarta, Pada tanggal 30 Januari 1992.

Manuaba, A. 1992a. Penerapan Ergonomi untuk Meningkatkan Kualitas Sumber Daya Manusia dan Produktivitas. Bandung. Makalah diSampaikan pada Seminar K3 dengan tema Melalui Pembudayaan K3 Kita Tingkatkan Kualitas sumber Daya Manusia dan Produktivitas Perusahaan di IPTN, 20 Februari 1992.

Manuaba, A. 1992 b. Penerapan Ergonomi untuk Meningkatkan Kwalitas Sumber Daya Manusia dan Produktivitas Perusahaan. Disampaikan pada Seminar K3 pada tanggal 20 Pebruari 1992 di IPTN Bandung.

Manuaba, A. 1998. Dengan Desain yang Aman Mencegah Kecelakaan dan Cedera. Bunga Rampai Ergonomi: Vol I. Program Pascasarjana Ergonomi-Fisiologi Kerja, Universitas Udayana, Denpasar.

Manuaba, A. 1999. "Ergonomi Meningkatkan Kinerja Tenaga Kerja dan Perusahaan". (Makalah). Bandung : Symposium dan Pameran Ergonomi Indonesia 2000, 18-19 November.

Manuaba, A. 2000. Ergonomi Kesehatan dan Keselamatan Kerja. Editor : Sritomo Wignyosubroto dan Stefanus Eko Wiranto. Prosiding Seminar Nasional Ergonomi 2000 di Surabaya. Guna Widya.

Nala, 1992, Penerapan Teknologi Tepat Guna Di Pedesaan, MPH, Pusat Pengabdian pada Masyarakat, Universitas Udayana, Denpasar.

Nasir, M. 2003. Metode Penelitian. Jakarta: Ghalia Indonesia.
Newman, D.G. 1990. Engineering Economic Analysis. Engeneering Press. Inc.

Nurmianto, E. 1996. Ergonomi: Konsep Dasar Dan Aplikasinya. Jakarta: Guna Widya.

Nursingbegin, 2011. Denyut Nadi Normal Manusia, (cited 2013 November 20), Aavailable From:http://nursingbegin.com/deny ut-nadi-normal-manusia.

Panero, J. dan Zelnik, M. 2003, Dimensi Manusia dan Ruang Interior. Jakarta, Erlangga.

Palilingan, R., Adiputra, I., Dinata, K., Dewi, A., 2012b. Analisis Sikap Kerja Dengan Menggunakan Metode REBA (rafid entire body assessment) Pada Buruh Angkat Angkut Wanita di Pasar Tradisional Badung Denpasar. Seminar IAIFI, Manado, 17-18 Mei 2012.

Palilingan, Richard. 2013. Pentingnya Ergonomi Dalam Segala Aspek Kehidupan. Bali express, 5 Maret, hal.4, kol.2

Palilingan, Richard. 2013. Aplikasi Ergonomi Pada Redesain Sapu Lidi Bertangkai Mengurangi Beban Kerja, Keluhan Muskuloskeletal dan Kelelahan Pada Penyapu Jalan Di Kota Denpasar.(tesis). Denpasar: Program Pascasarjana Universitas Udayana.

Peter, Vi. 2000. Musculoskeletal Disorders, (citid 2013 June 12). Available from

http://www.csao.org/uploadfiles/ma gazine/voll1no3/musculo.html

Pheasant, S. 1991. Ergonomic, Work and Health. London : Macmillan Academic Profesional Ltd.

Pulat, B.M. 1992. Fundamentals of Industrial Ergonomi. Hall International. Englewood Clift-New Jersey. USA 
Jurnal Ergonomi Indonesia

(The Indonesian Journal of Ergonomic)

Putra, I D.G.A. 2004. Penambahan Spon pada Gagang Gergaji Kayu dapat menurunkanKeluhan

Muskuloskeletal dan Beban Kerja serta Meningkatkan Produktivitas pada Tukang Kayu (tesis) Denpasar: Program Magister Ergonomi-Fisiologi Kerja, Program Pascasarjana Universitas Udayana.

Radiawan, 2008. Perbaikan Alat Kerja dan Cara Kerja Penyisitan Pandan Menurunkan Keluhan Muskuloskeletal dan Kelelahan serta Meningkatkan Produktivitas Perajin Tikar Pandan Di Desa Tumbu Karangasem (tesis) Denpasar: Program Magister Ergonomi-Fisiologi Kerja, Program Pascasarjana Universitas Udayana.

Robert R. : Lucyana W. 2009. 31 Inspirasi Rumah Modern Minimalis, Transmedia Pustaka.

Rodahl, K. 1989. The Physiology of Work. Philadelphia: Taylor \& Francis.

Rohmanhadi. 1984. Perhitungan Biaya Pelaksanaan Pekerjaan dengan Menggunakan Alat-alat Berat. Badan Penerbit Pekerjaan Umum.

Sanders, M.S. 7 Mc. Cormick. 1987. Human Factor in Engineering and Design. New York; Mc Graw-Hill Book Company.

Santiana, I M. A. 2004. Penggunaan Tulud Modifikasi Dapat Menurunkan Keluhan Otot Skeletal Dan Meningkatkan Produktivitas Petani Penggarap Sawah Di Desa Munggu Kecamatan Mengwi Kabupaten Badung (tesis) Denpasar: Program Magister Ergonomi-Fisiologi Kerja, Program Pascasarjana Universitas Udayana

Santoso, I G. 2013, Perbaikan Kondisi dan Lingkungan Kerja dengan Intervensi Ergonomi Meningkatkan Kinerja dan Mutu Produk pada Perajin Dodol di Desa Penglatan,
Buleleng (disertasi) Denpasar: Program Pascasarjana Universitas Udayana.

Sedarmayanti, 1996. Tata Kerja dan Produktivitas Kerja, Suatu Tinjauan Dari Aspek Ergonomic Atau Kaitan Antara Manusia Dengan Lingkungan Kerjanya, Penerbit Mandar Maju, Bandung.

Soerjani, M. 1987. Lingkungan Sumber Daya Alam dan Kependudukan dalam Pembangunan, Jakarta: Universitas Indonesia

Suma'mur, P.K. 1995. Higene Perusahaan dan Kesehatan Kerja, Jakarta: PT. Toko Gunung Agung.

Sutalaksana, I. Z. 1999. Produk-Produk Ergonomis dan Strategi Mewujudkanya. Dalam; Proceedings Simposium dan Pameran Ergonomic Indonesia 2000, Tehnology Business Operation Unit IPTN, Bandung I, p. 19-24.

Suyanto, S. 1985. Meningkatkan Produktivitas dengan Ergonomi. Jakarta: PT. Pustaka Binaman Pressindo.

Sutajaya, M. 1998. Perbaikan Kondisi Kerja Mengurangi Gangguan Terhadap Muskuloskeletal Dan Denyut Nadi Kerja Serta Meningkatkan Produktivitas Pematung di Desa Peliatan, Kecamatan Ubud, Kabupaten Gianyar (Tesis) Denpasar: Program Pascasarjana Universitas Udayana.

Sutajaya, M. 2006. Manfaat Praktis Ergonomi. Kerjasama Bagian Faal Fakultas Kedokteran Universitas Udayana Dengan Jurusan Pendidikan Biologi Fakultas Pendidikan MIPA Universitas Pendidikan Ganesha Singaraja Bali. Denpasar: Bagian Faal Fakultas Kedokteran Universitas Udayana. 
ISSN Print : 1411 - $951 \mathrm{X}$, ISSN Online : 20503-1716

Jurnal Ergonomi Indonesia

(The Indonesian Journal of Ergonomic)

Sutjana, I.D.P. 1998. Peningkatan Produktivitas Kerja Penyabit Padi Menggunakan Sabit Bergerigi Dibandingkan Dengan Sabit Biasa (Tesis) Denpasar: Program Pascasarjana Universitas Udayana.

Sutjana, I.D.P. dan Sutajaya, I.M. 2005. Penuntun Tugas Lapangan Mata Kuliah Ergonomi-Fisiologi Kerja. Denpasar: Universitas Udayana.

Tarwaka. 1991. Produktivitas dan Pemanfaatan Sumber Daya Manusia. Majalah Hiperkes dan Keselamatan Kerja Jakarta: XXIV(2):55-57

Tarwaka. 2011. Ergonomi Industri: DasarDasar Pengetahuan Ergonomi dan Aplikasi di Tempat Kerja. Cetakan Kedua. Surakarta : Harapan Press Solo.

The Joyce Institute. 1998. Workplace Ergonomics

http://www.Ergonomilljoyce work ergs.htm

Trinawindu I. B. K. 2010. Praktek Cetak Saring Yang Ergonomik Menurunkan Keluhan Muskuloskeletal Serta Meningkatkan Produktivitas Mahasiswa Di Studio Desain Komunikasi Visual, Fakultas Seni Rupa Dan Desain, Institut Seni Indonesia Denpasar.(tesis). Denpasar: Program Pascasarjana Universitas Udayana.

Wignyosoebroto. S. 2003. Ergonomi Studi Gerak dan Waktu. Surabaya. Penerbit Guna Widya. 1-12.

Wyon, D.P. 2004. The Effek Of Indoor Air Quality on Performance and Productivity. Abstrak. Indoor Air. 14 (Suppl 7):92-101 